\section{An impact assessment of the Child Growth, Development and Care Program in the Caribbean Region of Colombia}

\author{
Evaluación del Programa de Crecimiento y \\ Desarrollo y el Cuidado del Niño en Colombia: \\ sus efectos en la región Caribe
}

\author{
Avaliação do Programa de Crescimento, \\ Desenvolvimento e Cuidado Infantil na Colômbia: \\ seus efeitos na Região Caribe
}

\begin{abstract}
This article aims to assess the impact of the Child Growth, Development and Care Program in the Caribbean region of Colombia by analyzing variables such as maternal childcare practices and indicators of the nutritional status and health of children under the age of five. To this end, the authors used the quasi-experimental technique Propensity Score Matching. Positive impacts included a decrease in acute diarrheal disease, and an increase in immunization and seeking treatment for acute respiratory infection or fever symptoms. However, the program had little influence on chronic and acute malnutrition in the region.
\end{abstract}

Child Welfare; Regional Development; Statistics; Program Evaluation
Alcides de J. Padilla 1

Juan C. Trujillo 2

\section{Resumen}

Este artículo tiene como objetivo evaluar el impacto del Programa de Crecimiento y Desarrollo y el Cuidado del Niño en la región Caribe de Colombia. La evaluación se efectúa sobre variables como el estado nutricional, indicadores antropométricos y salud de los niños menores de cinco años de edad y las prácticas maternales de cuidado infantil. Para este propósito se emplean técnicas cuasi-experimentales de emparejamiento tipo Propensity Score Matching. Entre los resultados de la evaluación se encuentran una disminución de la enfermedad diarreica aguda, una inmunización más alta y la búsqueda de tratamiento para atender síntomas de infección respiratoria aguda o fiebre. Sin embargo, el programa tuvo poca influencia sobre la desnutrición crónica y desnutrición aguda en la región.

Bienestar del Niño; Desarrollo Regional; Estadística; Evaluación de Programas y Proyectos de Salud 


\section{Introduction}

One of the main priorities of governments is the design and implementation of public policies to improve welfare and enhance the quality of life of the population as a whole, and particularly children. The general lack of child welfare is a major concern for governments. According to a report by the World Health Organization (WHO) 1, approximately 6.9 million children under the age of five died in 2011 from causes including malnutrition, respiratory infections and diarrheal diseases. Children who survive such diseases are left with sequelae which affect their growth and development, and several studies confirm that educational productivity and performance depend largely on early childhood development 2 . Governments in developing countries have invested significant resources in various policies and social programs to tackle this problem; however, there is a continuing need to ensure a more efficient use of these resources 3 . Interventions include the provision of nutritional supplements, subsidized prices, cash benefits, and childcare programs. Despite these efforts, child care remains a public health priority.

Various social protection schemes addressing maternal and child health have been implemented in Latin America and the Caribbean, including: the Universal Mother and Child Insurance program (Seguro Universal Materno-Infantil - SUMI) in Bolivia, the Family Health Program (Programa Saúde da Família - PSF) in Brazil, the Free Maternity and Child Care Law (Ley de Maternidad Gratuita y Atención a la Infancia LMGYAI) in Ecuador, the Maternity-Child Bonus (Bono Materno-Infantil - BMI) in Honduras, and the Education, Health, and Nutrition Program (Programa de Educación, Salud, y Alimentación - PROGRESA) in Mexico. In Colombia, the first mother and child health protection program was the Mother and Child Protective Services Extension Program (Programa de Extensión de Servicios de Protección Materno Infantil), which was renamed the Mother and Child Program (Programa Materno Infantil - PMI) in 1973. This program aimed to reduce rates of maternal and child mortality and morbidity resulting from infectious and parasitic diseases, improve the coverage of preventive services, and reduce the prevalence of protein-calorie malnutrition ${ }^{4}$. These programs have led to a marked improvement in child malnutrition indicators since the 1970s 5 .

In 1987, in response to research conducted by the Colombian Institute of Family Wellbeing (Instituto Colombiano de Bienestar Familiar ICBF) focusing on comprehensive infant health, nutrition and stimulation in families living in extreme poverty and suffering from malnutrition, the Columbian government implemented the Community Homes Program (Programa de Hogares Comunitarios - HCB). To achieve greater efficiency in resource allocation and targeting, the government made a number of changes to this program, including conditional transfers that led to the creation of the Families in Action Program (Programa Familias en Acción). Another social protection program is the Growth and Development Program (Programa de Crecimiento y Desarrollo - PCD), which targets mother and child health and emerged as a result of UNICEF's (United Nations Children's Fund) request to include information on childcare and types of play related to early childhood development 6 . The PCD was created in the 1970s and has been subject to a number of changes since then, including Resolution n. 0412 of 2000 7, which introduced the so-called Technical Standard for the Early Detection of Changes in Growth and Development in Children Aged under the Age of Ten (Norma Técnica para la Detección Temprana de las Alteraciones del Crecimiento y Desarrollo en el Menor de 10 Años).

This standard comprises as a set of activities, procedures and interventions focused on the child population, including the need for regular and systematic care to ensure the timely detection of diseases, facilitate diagnoses and treatments, reduce the length of illness, prevent sequelae, reduce disability and prevent death 7 The standard focuses on children enrolled in the contributory and subsidized regimes from birth up to the age of 10 years, and the program's basic strategy is to educate parents about comprehensive health care for children. Typical services provided under the PCD include the development of medical histories, growth assessment, guidance to parents about the warning signs that require prompt consultation, investigation of the fulfillment of recommendations from previous consultation by physicians or nurses, performing physical assessments according age, and revising the vaccination schedule.

The program's main objective is the prevention of child mortality, in line with the current Millennium Development Goals set out by the United Nations Development Program (UNDP) which aim to reduce the mortality rate among children under the age of five by two thirds by 2015 . Colombia is committed to reducing mortality rates to 17 deaths per 1,000 live births in children under the age of five and to 14 deaths per 1,000 live births in children under the age of one. Through its Expanded Immunization Program (Programa Ampliado de Inmunizaciones - PAI), Colombia also seeks to achieve and main- 
tain $95 \%$ vaccination coverage for children under the age of five throughout the country.

According to the National Administrative Department of Statistics (Departamento Administrativo Nacional de Estadística - DANE) 9, the Caribbean region of Colombia accounts for $21 \%$ of total projected population, and $24 \%$ of the population of children under the age of five. Poverty levels in the region are the highest in the country: $37.2 \%$ of the country's population live below the national poverty line and $12.3 \%$ live in extreme poverty, compared to $56.7 \%$ and $22.6 \%$, respectively, in the Caribbean region. The Departments of Córdoba, La Guajira, Magdalena, Sucre and Cesar are ranked as the poorest in the country 10 . These figures demonstrate the extent of the problem faced by the Caribbean region of Colombia and the need to assess the impact of national poverty alleviation policies on the region.

Although there is a lack of assessment of the impacts of this kind of intervention at regional level, other programs targeting children have been the focus of national-scale evaluations, including the National Department of Planning's (Departamento Nacional de Planeación-DNP) 11 assessment of the Families in Action program (Familias en Acción), which showed that activities led to a reduction in the probability of children suffering chronic wasting of $7 \%$. The common denominator of these programs is their relative success in tackling nutrition problems, despite less favorable results in other areas of child development.

Similar social programs exist in other countries, such as "Conditional Cash Transfers" (Transferencias Monetarias Condicionadas), which provide monetary benefits to mothers if their children keep up-to-date with their vaccinations and preventive health visits, and/or attend school. The Oportunidades program in Mexico aims to help families to overcome extreme poverty and has the long term specific aim of reducing poverty and promoting the development of human capital in poor households through improvements in child nutrition, health and education 12. In Brazil, the Family Grant (Bolsa Familia) program, initially called the School Grant (Bolsa Escola) program, provides a monthly cash benefit to vulnerable families, provided that all school-age children achieve a $90 \%$ school attendance rate 13 . Other programs include the "Head Start" in the United States, and the Health and Education Program for Early Childhood Development in Jamaica. In Colombia, the design and implementation of Familias en Acción was inspired by the success of its Brazilian counterpart, the Bolsa Família. The main goal of these interventions is to promote maternal education and improve the nutritional status of children during early childhood.

This article aims to assess the impact of the Child Growth, Development and Care Program (Programa de Crecimiento, Desarrollo y Cuidado del Niño - PCDCN) in the Caribbean region, by analyzing variables such as maternal childcare practices and indicators of the nutritional status and health of children under the age of five. This study represents a step forward by becoming the first assessment of the regional impact of a national public health policy in Colombia.

\section{Methodology}

\section{Data}

The study used data obtained from Colombia's Demographic and Health Survey (DHS) conducted in 2010 by PROFAMILIA (Asociación Pro-bienestar de la Familia Colombiana). The DHS used a multistage probability sample design involving stratification and clustering to obtain a nationally representative sample of women of childbearing age, their spouses, and children under the age of five. The questionnaires used in the survey included questions about household socioeconomic and demographic characteristics. Mothers were asked whether their children under the age of five were enrolled in the PCDCN and to show their membership cards. The questionnaires contained modules on health, nutrition and childcare practices, from which we extracted the group of relevant variables used to assess the impact of the PCDCN.

Children were eligible to participate in the PCDCN if they were enrolled in the contributory or subsidized health regimes. The first of these systems is directed at people with formal labor income, while the second targets the poorest sector of the population. Eligible children were classified into two groups: "participants" and "nonparticipants". The first group consists of children enrolled in the PCDCN at time of the survey. Children who reported being PCDCN beneficiaries, but who did not show their membership cards were not included in the analysis. The use of this exclusion criterion did not result in a substantial loss of sample numbers (4\% of all children enrolled in the PCDCN). The nonparticipant group includes all potential beneficiaries who were not enrolled in the program at time of the survey. These variables are summarized in Table 1.

The total sample consisted of 3,648 children between zero and five years of age, of which approximately $74 \%$ participated in the program. 
Table 1

Description of the outcome variables.

\begin{tabular}{|c|c|}
\hline Outcome variable & Description \\
\hline \multicolumn{2}{|l|}{ Health } \\
\hline \multirow[t]{2}{*}{ Acute diarrheal diseases (ADD) } & Soft or watery defecation more than three times a day (or more often than normal for the person). \\
\hline & Structured as a dummy variable with a value of 1 if the person had ADD. \\
\hline \multirow[t]{3}{*}{ Acute respiratory infection (ARI) } & Group of diseases produced in the respiratory system caused by different microorganisms, such as viruses and \\
\hline & bacteria, which begin suddenly and last less than two weeks. \\
\hline & Structured as a dummy variable with a value of 1 if the person had ARI. \\
\hline \multirow[t]{8}{*}{ Comprehensive vaccination * } & Colombia has a comprehensive vaccination program for children aged under five years which includes the \\
\hline & following immunizations: Bacillus Calmette-Guerin (BCG) vaccine (one dose for children aged under a year), \\
\hline & Polio vaccine (four doses, newborns, two, four, and six months), Hepatitis B (three doses, newborn, two and \\
\hline & six months), Diphtheria, Pertussis and Tetanus (DPT) (three doses, two, four and six months), MMR (Measles, \\
\hline & Rubella, Mumps and Congenital Rubella) (one dose, one year), Tetanus/Diphtheria toxoids TT or Td (Neonatal \\
\hline & Tetanus and Diphtheria) (five doses), MEF (10 to 49 years), Haemophilus Influenzae Type B Hib (Pneumonia and \\
\hline & Meningitis) (three doses, two, four and six months), Yellow fever (one dose, over one year). \\
\hline & Dummy variable that takes the value of 1 if the individual has received the full vaccination, or otherwise 0. \\
\hline \multirow[t]{2}{*}{ Severe wasting } & Low weight-for-height. World Health Organization. \\
\hline & Structured as a dummy variable with a value of 1 if the person had severe wasting. \\
\hline \multirow[t]{2}{*}{ Moderate wasting } & Low weight-for-height and for sex, regardless of age. World Health Organization. \\
\hline & Structured as a dummy variable with a value of 1 if the person had moderate wasting. \\
\hline \multicolumn{2}{|l|}{ Child care practices } \\
\hline \multirow[t]{5}{*}{ Treatment of ADD } & Use of oral rehydration salts with low concentrations of glucose and salt, and zinc supplement, which can \\
\hline & drastically reduce the number of childhood deaths. Besides the prevention and treatment of dehydration with \\
\hline & appropriate fluids, breastfeeding, continued feeding and selective antibiotics, new methods reduce not only \\
\hline & the duration and severity of diarrheal episodes, but also frequency. \\
\hline & Dummy variable that takes the value of 1 if the individual had received treatment for ADD, or otherwise 0 . \\
\hline \multirow[t]{5}{*}{ Treatment of ARI/fever } & The treatment of ARI involves different levels of care, beginning with the pre hospital care. The primary \\
\hline & assessment steps are: airway with cervical spine control, proper ventilation, stable hemodynamic circulation, \\
\hline & and state of consciousness. Treatment beyond primary assessment involves three levels of care which depend \\
\hline & on the degree of complexity. \\
\hline & Dummy variable that takes the value of 1 if the individual had received treatment for ARI, or otherwise 0. \\
\hline
\end{tabular}

* Information about immunization was only available for children under two years of age.

Source: authors' estimates.

In addition to the total sample, the PCDCN also evaluates three categories of characteristics: individual, household and place of residence. The first includes the following variables: age of the head of household; age of the child's mother's; the child's mother's employment status; the child's mother's marital status; the child's mother's number of years of schooling; prenatal visits; whether the delivery was institutional; the child's sex; the child's age in months; and the child's birth order. The second category included the variables total number of family members, and the number of children under the age of five. The third category was divided into urban or rural.

The sample was stratified into three age subsamples: zero to two years, two to four years, and four to five years. The geographical study region was the Caribbean region of Colombia, divided into four sub-regions: the first sub-region, consisting of the Departments of La Guajira, Cesar and Magdalena; the second sub-region, comprising the District of Barranquilla (metropolitan area); the third sub-region, made up of the Departments of the Atlántico (without Barranquilla), San Andrés, and Bolívar (north); and the fourth sub-region, consisting of the Departments of Bolívar (the rest of the territory), Sucre and Cordoba.

A discriminate analysis of age and health scheme type was not performed, since this would considerably reduce sample size. For this reason, the effect of the program on the treatment of acute diarrheal diseases (ADD) was not analyzed by age sub-sample. 


\section{Empirical strategy}

The quasi-experimental technique Propensity Score Matching (PSM) was used for two reasons. First, due to the differences in characteristics related to the relevant variables between the participants and nonparticipants, which could lead to bias. Second, because the program does not provide universal coverage, allowing for a large control group with adequate variability. The study took into account the place of residence of the children, thus providing a technical evaluation of a program that, despite its importance for children's health in the Caribbean region, has never been assessed. The method used assesses the impact of the intervention by answering the hypothetical question: "what would have happened to the participants if the intervention had not been implemented?" 14 (p. 3). The counterfactual of the participants was derived by calculating the conditional probability of participation in the program as follows:

$P(Z=1 / X)$

More specifically, a nonparticipant (control group) represents the counterfactual of a participant (treatment group) when both are equally likely to participate in the program, based on a given set of covariables. One advantage of this procedure is that it summarizes the important characteristics of a number of individuals, which facilitates pairing. The underlying assumption behind this strategy is that the probability of participation in the program and the target variables depend only on the variables being observed by the researcher.

Thus, the average treatment effect (ATT) on the participants is given as follows:

$A T T=\mathrm{E}[\{\mathrm{E}[\mathrm{Y}(1) \backslash \mathrm{Z}=1, \mathrm{P}(\mathrm{X})\}-\mathrm{E}\{[\mathrm{Y}(0) \backslash \mathrm{Z}=$ $0, \mathrm{P}(\mathrm{X})\} \backslash \mathrm{Z}=1]$

Where $Y(1)$ and $Y(0)$ denote the observed result of the target variable in the control and treatment group, respectively. In this study, [2] is estimated by imposing the common support restriction; or more specifically, by using the minimum-maximum criterion, which discards the observations in each group whose participation is less likely/more likely than that of the minimum/maximum of the other group. We used a logit model with robust errors in the functional form to estimate probability of participation. To identify counterfactual results in the control group, pairing was performed using two techniques: maximum distance $(\mathrm{CM})$ and local linear regression (LLR).

\section{Maximum distance}

Often called caliper matching, the CM method matches the participants i with the nonparticipant $j$ with the highest probability of participation in a previously set neighborhood. The counterfactual j, $C(i)$, of participant $\mathrm{i}$ is given by:

$C(i)=\left\{j \in \mathrm{Z}=0\left\|P_{i}(X)-P_{j}(X)\right\| \leq \delta\right\}$

where $\delta$ is the maximum difference between the participation probabilities of the counterfactual $\mathrm{j}$ and the participants i. We set $\delta$ equal to 0.2 of the standard deviation of the participation probability 15 .

\section{Local linear regression pairing}

This algorithm is used to pair each participant with a weighted average of several or all individuals in a control group. The weight, $W_{i j}$, allocated to each control group individual depends on the distance between the participants $i$ in terms of participation probability: the more disparate the participation probabilities, the lower the weight allocated to the control group individual. Each weight was obtained by performing a weighted regression of $\mathrm{Y}(0)$ against the participation probability in a given neighborhood by participant group. It was therefore necessary to choose a kernel function, and we used the Gaussian kernel matching with a bandwidth of 0.06 . Thus, the ATT estimator can be expressed as follows:

$A T T=\Sigma_{\mathrm{i} \in \mathrm{Z}=1}\left[Y i-\Sigma_{\mathrm{i} \in \mathrm{Z}=0} W_{i j}\left(Y_{j}\right)\right]$

Standard error was calculated using bootstrap or Monte-Carlo simulation and adjusted for household clusters.

\section{Results}

Table 2 presents the descriptive statistics for the variables that may influence the probability of program participation and the outcome variables. These variables correspond with those commonly used by impact assessments of child health and nutrition interventions 16. Significant differences can be observed between the PCDCN participants and nonparticipants. It can also be noted that the number of PCDCN participants exceeds the number of nonparticipants.

It can be seen that the prevalence of moderate and severe wasting is higher among nonparticipants: a difference of 5 p.p. and 3 p.p. (participation probability), respectively. The indicator of nutritional status used in this analysis was the variable height-for-age which we standardized based on the difference between the child's height and the median height of healthy children of the same age (Z-score). In Figure 1, we present 
Means of demographic, geographic and economic variables of participants and nonparticipants for the overall sample and place of residence. Caribbean region, Colombia.

\begin{tabular}{|c|c|c|c|c|c|c|c|c|}
\hline & \multirow{3}{*}{$\begin{array}{c}\text { Variable } \\
0\end{array}$} & \multicolumn{7}{|c|}{ Caribbean region } \\
\hline & & \multirow[t]{2}{*}{ Total observation } & \multirow[t]{2}{*}{ Global mean } & \multicolumn{2}{|c|}{ Nonparticipants } & \multicolumn{2}{|c|}{ Participants } & \multirow[t]{2}{*}{ Difference } \\
\hline & & & & $\mathbf{n}$ & Mean & $\mathbf{n}$ & Mean & \\
\hline \multicolumn{9}{|l|}{ Output variables } \\
\hline Moderate wasting & Categorical & 2,567 & 0.16 & 841 & 0.19 & 1,726 & 0.14 & 0.05 * \\
\hline Severe wasting & Categorical & 2,567 & 0.05 & 841 & 0.07 & 1,726 & 0.04 & 0.03 * \\
\hline ADD & Categorical & 2,598 & 0.42 & 876 & 0.59 & 1,722 & 0.36 & 0.23 * \\
\hline ARI & Categorical & 1,498 & 0.16 & 472 & 0.17 & 1,026 & 0.17 & 0.003 * \\
\hline Comprehensive vaccination & Categorical & 471 & 0.88 & 177 & 0.82 & 294 & 0.89 & $-0.07 *$ \\
\hline Treatment of ARI/fever & Categorical & 759 & 0.53 & 511 & 0.41 & 248 & 0.57 & -0.15 * \\
\hline Treatment of ADD & Categorical & 1,252 & 0.46 & 156 & 0.33 & 1,096 & 0.50 & -0.16 * \\
\hline \multicolumn{9}{|l|}{ Individual characteristics } \\
\hline Age of head of household & Continuous & 2,611 & 44.76 & 880 & 40.53 & 1,731 & 41.83 & -1.30 * \\
\hline Age of mother & Continuous & 2,611 & 19.56 & 880 & 19.70 & 1,731 & 20.20 & -0.50 \\
\hline Mother employed & Continuous & 2,611 & 4.55 & 880 & 6.10 & 1,731 & 4.80 & 1.30 * \\
\hline Mother married & Categorical & 2,611 & 2.21 & 880 & 2.12 & 1,731 & 2.14 & -0.02 \\
\hline Maternal years of schooling & Continuous & 2,604 & 6.83 & 877 & 7.25 & 1,727 & 8.41 & -1.16 * \\
\hline Prenatal visits & Discrete & 2,611 & 0.87 & 880 & 0.80 & 1,731 & 0.92 & $-0.11 \star$ \\
\hline Institutional delivery & Categorical & 2,611 & 20.14 & 880 & 19.70 & 1,731 & 20.68 & -0.97 * \\
\hline Boy & Categorical & 2,611 & 0.52 & 880 & 0.54 & 1,731 & 0.53 & 0.01 \\
\hline Child's age in months & Categorical & 2,568 & 26.31 & 851 & 19.09 & 1,717 & 24.97 & $-5.87 *$ \\
\hline First-born & Categorical & 2,611 & 0.36 & 880 & 0.31 & 1,731 & 0.37 & -0.06 * \\
\hline Second-born & Categorical & 2,611 & 0.27 & 880 & 0.27 & 1,731 & 0.27 & 0.00 \\
\hline \multicolumn{9}{|l|}{ Household characteristics } \\
\hline Number of family members & Discrete & 2,611 & 5.83 & 880 & 6.20 & 1,731 & 5.87 & 0.32 * \\
\hline Number of children aged under 5 years & Discrete & 2,611 & 0.90 & 880 & 1.84 & 1,731 & 1.66 & 0.18 \\
\hline \multicolumn{9}{|l|}{ Place of residence } \\
\hline Urban & Categorical & 2,611 & 0.66 & 880 & 0.59 & 1,731 & 0.68 & -0.09 \\
\hline
\end{tabular}

ADD: acute diarrhoeal diseases; ARI: acute respiratory infection.

* Statistically significant at the $1 \%$ level.

Source: Colombia's Demographic and Health Survey (DHS) 2010, World Health Organization (WHO) and authors' estimates.

the kernel density estimation of height-for-age (Z-score) for children under the age of five in the reference region. According to WHO standards, a child whose height is between two and three standard deviations below the median heightfor-age is suffering from moderate and severe wasting, while a child whose height is more than three standard deviations below the median is suffering from severe wasting 17 . The results indicate that chronic wasting in children in the Caribbean region is a concern, despite the existence of programs to mitigate this problem.

The prevalence of ADD was significantly higher (a difference of approximately 0.23 p.p.) among nonparticipants. However, the results for acute respiratory infection (ARI) and ADD treatment for both participants and nonparticipants were very similar (difference of 16 p.p. and 17 p.p. respectively). The average number of antenatal visits was higher among mothers of participating children. The average age of the head of household is approximately 45 years, while the average age of mothers, considering the last childbirth, is 19 years. As for schooling, mothers of participating children completed an average of one more year of schooling than nonparticipants. Mothers of participating children had worked approximately 1.31 days less in the past week than mothers of nonparticipants. The results for certain variables (for example institutional delivery, mother's marital status, child's sex and number of children under the age of five) were similar for both participants and nonparticipants. The participation probability for place of residence 


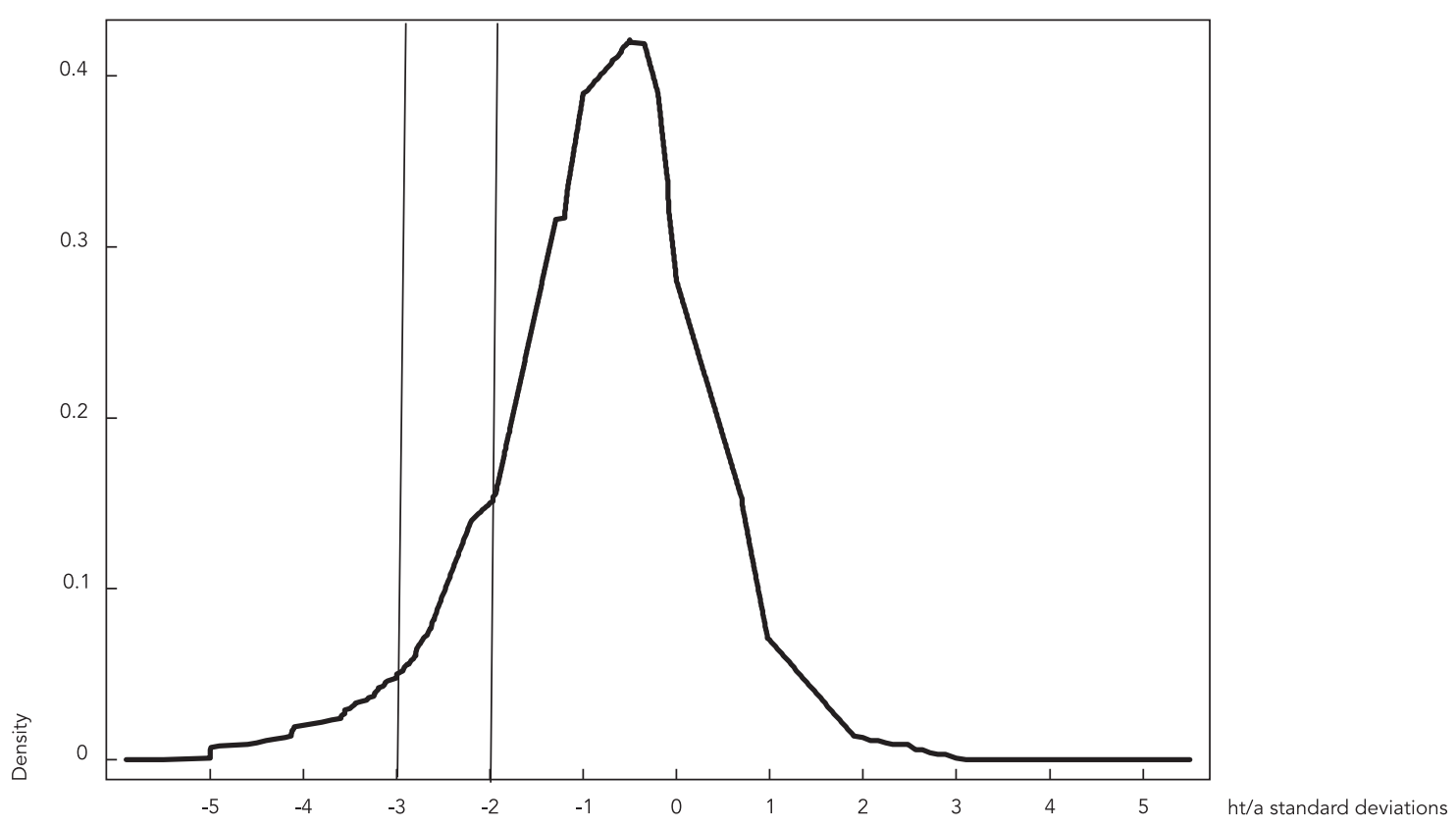

Note: the black line represents the standard deviations (-2 to -3$)$.

Kernel density estimation (Z Score)

Kernel = espanechnikov, band with $=0.1584$

Source: authors' estimates.

(urban) for participants and nonparticipants was 0.68 and 0.59 , respectively.

The average age of participants and nonparticipants was 24.97 and 19.09 months, respectively. Thirty-seven percent of the children participating in the PCDCN and $31 \%$ of nonparticipants were first-borns.

In summary, the evidence suggests that the majority of program participants lived in urban areas and were from households with fewer members than nonparticipants. The mothers of children participating in the program tended to make more prenatal visits, were more likely to give birth in a hospital, worked shorter hours, and had a higher level of education than the mothers of nonparticipants. Impact assessments should consider the socioeconomic and demographic differences between program participants and nonparticipants. Failure to do so could result in a biased estimate of the impact of the PCDCN.

\section{Results of estimates}

The logit model used to estimate participation probability presents a good fit with all estimated models. The final specification for each model was obtained recursively. We performed iterations until there was no significant difference from one iteration to the next in the explanatory variables of participants and nonparticipants for each "strata" of participation probability. The average number of observations was 2,561. The significant variables were age of head of household, mother's occupation, years of maternal schooling, prenatal visits, institutional delivery, child's age in months, first-born child, and total number of family members. A criterion was established to choose the optimal number of strata 18 . The optimal number of strata was 8 . The variables that have the greatest influence on participation in the program are household composition, mother's characteristics and geographic location (Figure 2). 


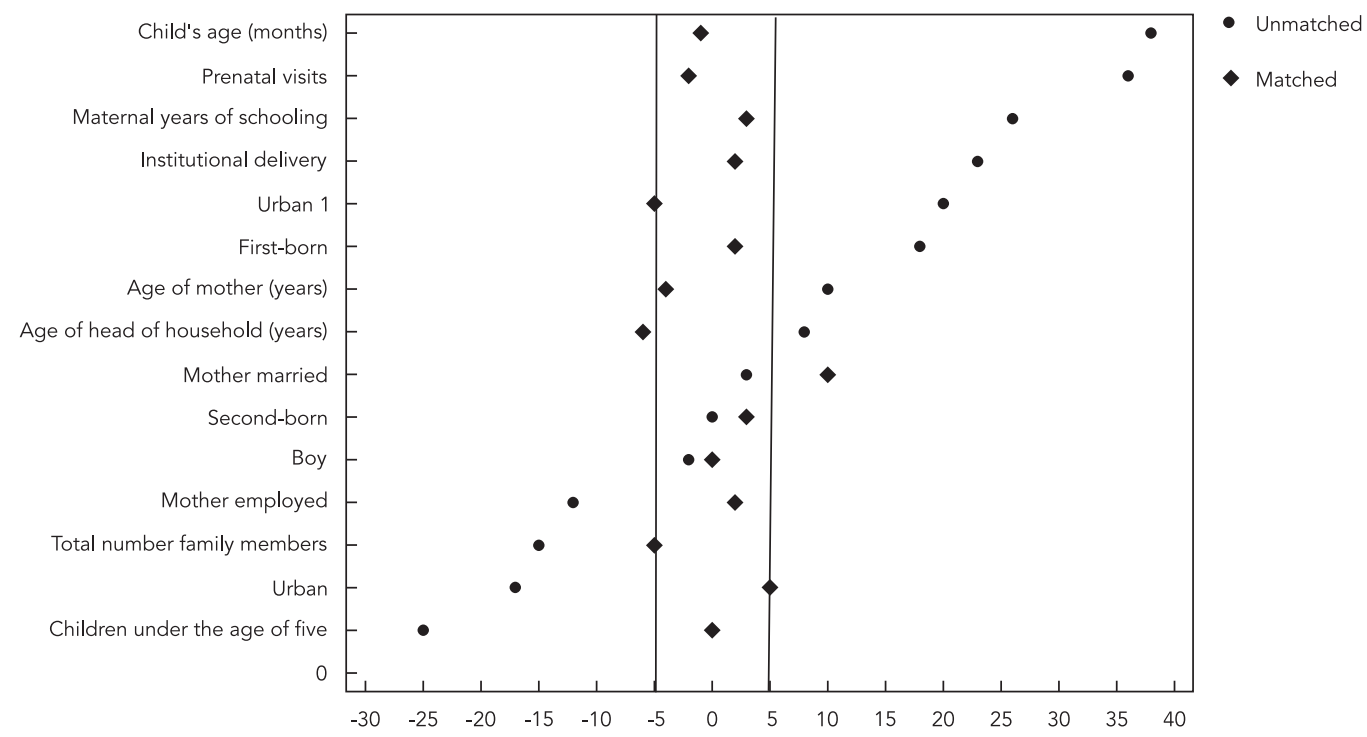

Note: the black line represents the threshold of tolerance (3.5\% to $5 \%$ ).

In addition, children from families with fewer children aged between zero and five years and whose mothers do not work are more likely to be enrolled in the PCDCN. The likelihood of enrolling children in the program also increases with increasing number of prenatal visits and years of maternal schooling. Territoriality was not considered a determinant among program participants due to collinearity and nonsignificance problems with the rural variable.

The ATT estimates for the Caribbean region are shown in Table 3. The results indicate that the PCDCN has a positive impact on ADD reduction, comprehensive vaccination and the treatment of ARI/fever. More specifically, participation in the program increases the probability of a child completing the full series of immunizations for his/her age by almost 6 p.p., while participants are 12 p.p. more likely than nonparticipants to receive medical treatment for ARI or fever symptoms. The program has no impact on other outcome variables and the impact on the prevalence of ADD is negative.

\section{Discussion}

The assessment of the impact of the PCDCN in the Caribbean region of Colombia showed that there was a decrease in ADD and an increase in immunization and seeking treatment for ARI or fever symptoms due to the program. It can be observed that there was a loss of values in the sample related to both vaccination and ARI treatment. However, the robustness of the PSM results and the fact that the sample remained significant meant that this did not limit the results (Table 2). It is important to note that the program had no impact on severe wasting and moderate wasting in the region. Lack of maternal education regarding early childhood care, a factor which seems to play a major role in the region, may partly explain this finding. There is evidence to suggest that wasting is a major cause of the high prevalence of ADD 19. The data provides irrefutable evidence of a problem regarding the relationship between ADD and nutritional status, implying that the effects of the PCDCN are essentially confined to children from the region's poorest families. The results regarding acute and chronic malnutrition are similar at the regional level. Possible reasons to explain this fact are the heterogeneity of regions and different health programs 20 . 
Estimates of the average treatment effect (ATT) on program participants in the Caribbean region, Colombia.

\begin{tabular}{lcc}
\hline Variable & Caribbean region & ATT ** \\
& ATT * & $-0.01921(0.01593)$ \\
Moderate wasting & $0.00116(0.02145)$ & $-0.01518(0.01149)$ \\
Severe wasting & $-0.012865(0.01359)$ & $-0.06904 * \star *(0.04173)$ \\
ADD & $-0.00116(0.05264)$ & $0.00460(0.02479)$ \\
ARI & $0.02150(0.02846)$ & $0.06445 * * *(0.03696)$ \\
Comprehensive vaccination & $0.04421(0.04958)$ & $0.12355 \#(0.03306)$ \\
Treatment of ARI/fever & $0.14692 \#(0.03649)$ & $0.08617(0.07073)$ \\
Treatment of ADD & $0.09274(0.06936)$ &
\end{tabular}

ADD: acute diarrhoeal diseases; ARI: acute respiratory infection.

Estimates were made using replacement and common support:

* PSM using caliper matching;

** PSM using local linear regression and bootstrap simulation to calculate standard error and determine statistical significance.

Bootstrap standard error adjusted by imposing the common support restriction:

*** Statistically significant at the $10 \%$ level;

\# Statistically significant at the $1 \%$ level.

Source: Colombia's Demographic and Health Survey (DHS) 2010, World Health Organization (WHO) and authors' estimates.

Regarding the prevalence of ADD, considered one of the leading causes of death among children aged under five years worldwide 21 , the program showed positive results: a difference of 23 p.p. between children participating in the program and nonparticipants can be observed (see Table 2). Estimates based on data from the DHS (2010) show that overall prevalence of ADD in the region is $14 \%$. Prevalence rates are highest in the Departments of Atlántico and Magdalena (10\% and $18 \%$, respectively).

The PCDCN had no impact on severe wasting across all of the evaluated groups. A similar result was found by an assessment of the Bangladesh Integrated Nutrition Project (PINB) which also showed that the project had no significant impact on wasting in children 22 . However, our results differ from those found by an assessment of the Bolsa Familia program in Brazil which found that the intervention led to an improvement in nutritional status among participating children 23. Our results also differ from the findings of a study conducted by the ICBF of the HCB program. Ambiguous evidence of the impact of this program has been found. While there have been gains with respect to chronic wasting among children aged between two and four years, the program had a negative effect on the prevalence of acute respiratory infection and diarrhea. The impact of the subsidized health scheme was also determined. One possible reason for this difference is that the HCB program only targets poor families, and we did not perform a discriminate analysis of household economic status and age group in the present study 24 .

With regard to measuring program impact, it is important to note that PSM enabled the fulfillment of the conditional independence assumption. In other words, after controlling for all relevant observed characteristics, the control group should show the same average results as the treatment group in the absence of intervention.

One of this study's limitations is that it is not adequate for making predictions about long term impact assessments.

The Families in Action Program mentioned above uses more variables related to child growth, development and care in Colombia than the PCDCN. The lack of variables used by the PCDCN can be considered a limitation. However, although it is advisable to assess the maximum possible number of determinants of participation, controlling this amount of variables is often complex. This consideration is particularly important when it comes to the fulfillment of the common support hypothesis, which is critical for correctly characterizing PSM. Finally, we recommend that future studies should use a larger sample size to allow for the simultaneous comparison of different variables, thus facilitating the observation of various program impacts. In addition, future studies should also consider the length of time that children have been in the program and use temporal information to improve estimates related to the household income of participating children. 


\section{Resumo}

Este artigo tem como objetivo a avaliação do impacto do Programa de Crescimento, Desenvolvimento e Cuidado Infantil na região do Caribe colombiano. A avaliação é realizada em variáveis como status nutricional, indicadores antropométricos, saúde das crianças menores de cinco anos de idade e as práticas de cuidados infantis maternos. Para isso, são utilizadas técnicas quase experimentais do tipo Propensity Score Matching. Entre os resultados da avaliação, verificou- se uma diminuição da doença diarreica aguda, uma imunização mais alta e a busca pelo tratamento de sintomas de infecção respiratória aguda ou febre. Porém, o programa teve pouca influência sobre a desnutrição crônica e a desnutrição aguda na região.

Bem-Estar da Criança; Desenvolvimento Regional; Estatística; Avaliação de Programas e Projetos de Saúde

\section{Contributors}

A. J. Padilla participated in study design, the writing of this article, and read and approved the final version of this manuscript. J. C. Trujillo participated in data collection, the writing of this article, and read and approved the final version of this manuscript.

\section{Acknowledgments}

We wish to thank Mr. José Redondo and Mr. Raúl Velilla for their diligent assistance in data processing.

\section{References}

1. World Health Organization; United Nations Children's Fund; The World Bank; Population Division, Department of Economic and Social Affairs, United Nations. Levels \& trends in child mortality. Report 2012. New York: United Nations Children's Fund; 2012.

2. Macours K, Schady N, Vakis R. Cash transfers, behavioral changes, and cognitive development in early childhood: evidence from a randomized experiment. Am Econ J Appl Econ 2012; 4:247-73.
3. Frongillo EA, Tofail F, Hamadani JD, Warren AM Mehrin SF. Measures and indicators for assessing impact of interventions integrating nutrition, health, and early childhood development. Ann N Y Acad Sci 2014; 1308:68-88.

4. Organización Panamericana de la Salud. Organización Panamericana de la Salud y el Estado Colombiano: cien años de historia, 1902-2002. Bogotá: Organización Panamericana de la Salud; 2002. 
5. Garcia S, Sarmiento L, Forde I, Velasco T. Socioeconomic inequalities in malnutrition among children and adolescents in Colombia: the role of individual-, household- and community-level characteristics. Public Health Nutr 2013; 16: 1703-18.

6. Ministerio de Salud y Protección Social. Encuesta Nacional de Demografía y Salud del 2010 (ENDS 2010). Profamilia. Bogotá: Ministerio de Salud y Protección Social; 2010.

7. Ministerio de Salud. Resolución 0412 de 2000. Norma técnica para la detección temprana de las alteraciones del crecimiento y desarrollo en el menor de 10 años. Bogotá: Ministerio de Salud; 2000.

8. Naciones Unidas. Podemos erradicar la pobreza 2015. Objetivos de desarrollo del milenio. New York: Naciones Unidas; 2014.

9. Departamento Administrativo Nacional de Estadística. Estimaciones de población (1985-2005) y proyecciones de población (2005-2020) nacional y departamental desagregado por área, sexo y grupos quinquenales de edad. Bogotá: Departamento Administrativo Nacional de Estadística; 2012.

10. Departamento Administrativo Nacional de Estadística. Estadísticas de pobreza y desigualdad. Incidencia de la pobreza y pobreza extrema. Bogotá: Departamento Administrativo Nacional de Estadística; 2010.

11. Departamento Nacional de Planeación. Programa Familias en Acción - resultados de impacto un año después de implementado el programa. Evaluación de políticas públicas. Bogotá: Departamento Nacional de Planeación; 2006.

12. Darney BG, Weaver MR, Sosa-Rubi SG, Walker D, Servan-Mori E, Prager S, et al. The oportunidades conditional cash transfer program: effects on pregnancy and contraceptive use among young rural women in Mexico. Int Perspect Sex Reprod Health 2013; 39:205-14.

13. Veras F, Perez R, Guerreiro R. Evaluating the impact of Brazil's Bolsa Família: cash transfer programs in comparative perspective. Lat Am Res Rev 2010; 45:173-90.

14. White H, Barbu A. Impact evaluation - the experience of the independent evaluation group of the World Bank. Washington DC: World Bank; 2006.
15. Austin PC. Optimal caliper widths for propensityscore matching when estimating differences in means and differences in proportions in observational studies. Pharm Stat 2011; 10:150-61.

16. Andrade MV, Chein F, Souza LR, Puig-Junoy J. Income transfer policies and the impacts on the immunization of children: the Bolsa Família Program. Cad Saúde Pública 2012; 28:1347-58.

17. World Health Organization; United Nations Children's Fund. WHO child growth standards and the identification of severe acute malnutrition in infants and children. A joint statement. Geneva: World Health Organization; 2009.

18. Dehejia RH, Wahba S. Propensity score matching methods for nonexperimental causal studies. Rev Econ Stat 2002; 84:151-61.

19. Moore SR, Lima A, Schorling JB, Barboza MS, Soares AM, Guerrant RL. Changes over time in the epidemiology of diarrhea and malnutrition among children in an Urban Brazilian Shantytown, 1989 to 1996. Int J Infect Dis 2000; 4:179-86.

20. Carrillo B, Iglesias W, Trujillo JC. Attainments and limitations of an early childhood programme in Colombia. Health Policy Plan 2014; 30:906-16.

21. World Health Organization; United Nations Children's Fund; The World Bank; Population Division, Department of Economic and Social Affairs, United Nations. Levels \& trends in child mortality. Report 2014. New York: United Nations Children's Fund; 2014.

22. White H, Masset E. Assessing interventions to improve child nutrition: a theory-based impact evaluation of the Bangladesh Integrated Nutrition Project. J Int Dev 2007; 19:627-52.

23. Morris SS, Olinto P, Flores R, Nilson EA, Figueiró AC. Conditional cash transfers are associated with a small reduction in the weight gain of preschool children in Northeast Brazil. J Nutr 2004; 134: 2336-41.

24. Bernal R, Peña X. Guía práctica para la evaluación de impacto. Bogotá: Ediciones Uniandes; 2011.

Submitted on 13/Oct/2014

Final version resubmitted on $23 / \mathrm{Feb} / 2015$

Approved on 14/Apr/2015 